\title{
The power of place: Trauma recovery and memorialization
}

\author{
Stephanie Arel \\ New York University, USA \\ snarel@bu.edu
}

\begin{abstract}
In this paper, places of trauma, physical locations that reflect the Celtic spiritual concept of "thin places," simultaneously represent real life events, possess symbolic meaning, and become places for active, engaged social activity related to memorialization. I explore how these places create a potential space for working through trauma, drawing on Judith Herman's fundamental stages of recovery which she articulates as "establishing safety, reconstructing the trauma story, and restoring the connection between survivors and their communities." ${ }^{\prime}$ I argue that memorial museums attending to trauma can guide the process of working through suffering to growth and transformation, thus benefiting witnesses, survivors and family members, and employees who immerse themselves in the stories they memorialize in order to facilitate empathy and emotional availability to visitors of all types. This community commemorating communal trauma illustrates the Ricoeurean imperative - to remember, we need the other.
\end{abstract}

Key words

Trauma; memorials; museums; Paul Ricoeur; Judith Herman

\section{Introduction}

Considering a trauma of place presses an inquiry into historic sites, memorials and museums which tell the stories of individual and communal trauma. In this paper, I will consider such places as holding traumatic memory while encompassing Henri Lefebrve's concept of "'real space'...

1 Judith Herman, Trauma and Recovery (New York: Basic Books, 1992), 3. 
[as] the space of social practice." ${ }^{2}$ As sites of social practice, places of trauma are physical locations that simultaneously represent real life events, possess symbolic meaning, and become places for active, engaged social activity including communal gatherings, anniversary ceremonies, and reenlistment services. People, including survivors and family members, visit these sites to remember, grieve, pay homage, and discover the vestiges of trauma. Employees, too, negotiate traumatic content daily, most going beyond normal job requirements as they immerse themselves in the stories they memorialize in order to facilitate empathy and emotional availability to visitors of all types. This community commemorating communal trauma illustrates the Ricoeurean imperative - to remember, we need the other.

Ushering participants into the realm of social activity and inquiry engagement at places of communal trauma introduces key questions: how do sites of memory foster individual and social practices that engender transformation and growth from the trauma the site commemorates? What happens to trauma in such places - not only the contextual trauma of the site of memorialization but also to the traumas and traumata individuals bring to it from their own experience? Last, if we interpret space, in Lefebrve's terms as having the capacity to create change, then how do such places bolster reconnection after trauma? To answer these questions, I consider particular places that remember communal trauma, primarily addressing the 9/11 Memorial \& Museum in New York City, where I was involved in research from 2017-2019.

To explore how places of trauma create a potential space for working through trauma, I draw on Judith Herman's fundamental stages of recovery from trauma which she articulates as "establishing safety, reconstructing the trauma story, and restoring the connection between survivors and their communities." ${ }^{3}$ Trauma survivors experiences these stages repetitively over time, not linearly, at different levels of intensity. And the movement through each stage requires assurance of empowerment for the victim or survivor and human relationships, as recovery from trauma never happens in isolation.

2 Henri Lefebrve, The Production of Space, trans. Donald Nicholson-Smith (Oxford: Blackwell Publishers, 1991), 14.

3 Judith Herman, Trauma and Recovery (New York: Basic Books, 1992), 3. 
This paper argues that places that bear the wounds of trauma offer a symbolic way of engaging in recovery; when people visit such places together and interact with the site in a conscious way, the potential to produce a change increases. Further, understanding the phenomenon of trauma, highlighted in places where mass death and destruction have occurred, alongside the actuality of the lengthy process of integration enables action that might lead to the transformation of trauma into meaning. Edmund Husserl's concept of "imaginative variation" offers a means by which to understand how place and social activity at particular sites encourage psychological processes. ${ }^{4}$ Calling this practice "free play," Husserl asserts that exercising the imagination to seek meaning is both definitive of essential experience and a means of showing that the abstract can meet real-life. Exercises of conscious building and being aware of the way survivors work through trauma while at a site of trauma can lead to important lived insights on the lived body, lived situatedness, and place.

To further probe how place figures in this means of integrating trauma, I offer the Celtic spiritual concept of thin places, physical locales in which the division between the world and the sacred narrows. Often locations which have witnessed suffering afford a meeting of the seen and unseen, of death and life, of past and present, or in theological terms, of the earthly and the divine. These places hold actual memories, which during the recovery from trauma can feel elusive or intrusive. In this frame, the lived body experiences what can be interpreted as thin places and the activities held within them in ways that encourage post-traumatic recovery, producing transformation on human and spiritual levels.

When trauma permeates place, where the wounds of history lie open, it attenuates the distance between past memories and present practice, assuming the potential to arrest witnesses and to confer - in the face of horror - silence. In their analysis of the concentration camps of WWII and the children of survivors who visit them, Shoshana Felman and Dori Laub assert that the place that holds "the greatest density of silence - the place of concentration where death took place - paradoxically becomes, for those children of survivors, the only place that can provide access to

4 See Edmund Husserl, Cartesian Meditations: An Introduction to Phenomenology, trans. Dorion Cairns (1950; reprint, Dordrecht: Klewer Academic Publishers, 1999). 
the life that existed before their birth." ${ }^{2}$ At Auschwitz-Birkenau and the Płaszów Concentration camp in Krakow, the presence of both death and life haunting the space is palpable.

Even as historic sites that attest to trauma feel haunted by past tragedy, they also introduce the potential for new interpretations of meaning, for self-growth upon reflection, and thus offer, in their convergences, the possibility of transition and transformation. My point, then, is to draw conscious attention to the convergences when death meets life in memory. Acknowledging the fact that places which honour past memory have the potential to enable safety in the body as it experiences sensations and feelings, encourage memory recall and mourning, and foster reconnection with others and with the world makes these aspects of trauma recovery more plausible. I outline this sort of thin place as a locus of suffering that comes to fruition in its reconstruction as the symbolic form of memorialization, evidenced for instance at the 9/11 Memorial \& Museum, to consider how landscapes and structures facilitate recovery from trauma. My desire is to highlight not only the importance of memorializing and remembering the victims of tragedy - a "moral duty" in Paul Ricoeur's lexicon that serves as an illustration of the "debt we owe to the victims" - but also to recognize how survivors and others inhabiting the thin places of trauma move through the work of memory towards growth and transformation.

\section{The experience of trauma and thin places}

Trauma interrupts time, creating a gap between the "the occurrence of the traumatic event and the subsequent awakening to it." $A$ trauma survivor living in the gap may have symptoms of their experience, for instance nightmares, exacerbated stress, or physical symptoms, but fail to attach these symptoms to a traumatic event. At some point though, if an "awakening" occurs, a present event elicits recall of the trauma drawing

5 Shoshana Felman and Dori Laub, M.D., Testimony: Crisis of Witnessing in Literature, Psychoanalysis, and History (New York: Routledge, 1992), 64.

6 Paul Ricoeur, Figuring the Sacred: Religion, Narrative, and Imagination, trans. David Pellauer (Minneapolis: Fortress Press, 1995), 290.

7 Shelly Rambo, Spirit and Trauma: A Theology of Remaining (Louisville: Westminster John Knox Press, 2010), 20. 
the survivor rapidly back to the past. Under these conditions, time and space collide confusing interpretations of present happenings, as memories resurrect themselves. For the individual who has experienced trauma and for the individual memorializing victims of trauma, the suffering of previous trauma invades the present in cohesive and non-cohesive ways, as perceivable visual images such as flashbacks; as body memories, such as trembling or hypervigilance when there is no presence of threat; and as memories that confuse a safe present reality with past danger. The shifting and absences in time related to traumatic memory which remind us of past suffering are affective, visceral sensations that seize bodies and direct action. This collision of time and the representation of conflicting realities can be understood through the Celtic concept of thin places.

Described as an in-between place that merges the natural and sacred worlds, where the ordinary and non-ordinary mingle sharing common ground, thin places are geographical locations where one encounters a more "ancient reality" or where "in a glance we are somehow transported to the future." Heaven and earth, the Celtic saying goes, are only three feet apart, but in thin places that distance is even shorter. At these topographical locations, the barrier between the real world and what we consider transcendent attenuates. Something changes. The shift is subtle, but affective, precipitating sensations and feelings, defining that ground as a space where the past, present, and future coexist.

Although in the Celtic tradition, thin places are often characterized by their presence as natural phenomena, several core elements of thin places emerge in memorial sites of trauma. They are places where temporal distinctions disintegrate. They present the juxtaposition of apparent opposites: past/ present, visible/invisible, and earthly/transcendent. They remind witnesses and those who regularly inhabit them of the cost of trauma and conflict and thus contribute to the comprehension of growth after trauma. They also attest to trauma itself. According to Peter Gomes, thin places are likely to be found where there has been great suffering. Along with joy and mystery, Gomes asserts, thin places serve as points where the suffering of "the human and the divine come into the most intimate and profound

8 Edward C. Sellner, Wisdom of the Celtic Saints (Notre Dame, IN: Ave Maria Press, 1993), 25. 
proximities." This is not to uplift suffering but rather to acknowledge that the experience of suffering unites "all human experience in all ages" and can do so at physical sites. ${ }^{10}$

The intersection of geography, history, and memory, where suffering was endured, and where past, present, and future collide, actualizes edifices of memorialization as thin places. Because of how they honour the memory of atrocities in the service of justice, memorial museums eradicate great distance between this world and the spiritual world as structure that contain both the seen and the unseen in the face of trauma. They represent the visible and invisible wounds of trauma which indicate symbolic and human loss.

For instance, at the 9/11 Memorial, the original footprints of the Twin Towers contain the twin reflecting memorial pools, set within the footprints where the Twin Towers once stood and surrounded by durable swamp white oak trees. The names of every person who died in the 1993 and 2001 attacks are inscribed into bronze panels edging the pools, a powerful reminder of the massive loss of life there. This evidence of the space as wounded ground extends to the reality that it is also the actual resting place for many of the 2,983 people who died there: 2,977 who died on September 11, 2001 and six who died as a result of the 1993 World Trade Centre bombing. Further, situated between the remains of the two towers in the museum, behind an art installation by Spencer Finch entitled "Trying to Remember the Colour of the Sky on that September Morning" is a repository for the remains of the unidentified 9/11 victims held temporarily or in perpetuity unless identifications are made, an effort that is ongoing by medical examiners. Thus, the memorial and museum is at once a public site and a cemetery, and as ground that continues to hold suffering represents a thin place.

Since trauma elicits hopelessness, fragmentation, and often despair, rebuilding after destruction and the reconstruction of memory is necessary for both the individual and society. The arrangement, construction, and art

9 Peter J. Gomes, The Good Book: Reading the Bible with Mind and Heart (San Francisco: Harper Collins, 1996), 214.

10 Ibid. 
in memorial spaces facilitate the movement from the past to the future. At the 9/11 Memorial \& Museum, the fact that the existing space is a reconstruction of what was a gaping hole in lower Manhattan brings this point to bear. What was once a hole that reeked of devastation, is now a reimagination, aesthetically meant to have certain effect, one aimed at both connection and safety. It also is a place of "aliveness" 11 which combats the often dead feeling that trauma evokes. Many survivors of the World Trade Centre attacks name the memorial plaza as a sombre and respectful place which marks suffering, but also attests to life, growth and possibility. It is a "living memorial," and as much as it evokes the memory of the dead it also draws the traumatized into new life, allowing them to feel again.

\section{Establishing safety}

In new creation, whether psychologically, biblically, or symbolically conceived, lies the need for reassurance of protection from harm. In Herman's proposal, establishing a secure foundation epitomized in safety is the first and foundational stage of trauma recovery. Therefore, reflecting on the essence of safety through the lens of trauma as well as the ways that memorials and museums mobilize space to create safety is integral to examining how places of trauma can be re-imagined and manipulated to facilitate recovery.

Safety is about bringing the body back to regulation and entails believing that the body is no longer threatened. Therefore, establishing safety begins with the body, and secondarily moves outward to incorporate the feeling that one has control over the environment. ${ }^{12}$ Command over the environment includes the ability to recognize stressors and then respond to these with measures of self-care. Those who feel the effects of trauma benefit from building skills to assess both present and long-term needs for safety and trust in their ability to seek help when help is needed therefore forging secure relationships.

11 For use of this term see, Ann Belford Ulanov, The Unshuttered Heart: Opening Aliveness/ Deadness in the Self (Nashville: Abingdon Press, 2007).

12 Herman, Trauma and Recovery, 160. 
Achieving the necessary element of feeling safe in one's body often includes diligent involvement in activities that combat issues of passivity and helplessness entailing: "play and exploration, artistic and creative pursuits, and some form of involvement with others." ${ }^{13}$ Such creativity, evident in the work of the Igbo artists, is also apparent in responses to staff expressions of susceptibility to threat at the 9/11 Memorial \& Museum. Security at this location responded with a three pronged approach: listening to staff to discern real versus perceived vulnerability, analysing where the real fear lay and addressing it, and offering reassurance by ensuring that staff stay familiar with all the things that have been put into place to ensure their safety of which they may not have been aware including police presence around the museum, the employment of bomb dogs, and the use of the magnetometer and x-rays to survey all who enter the space. This kind of contest against passivity in favour of action and initiative enables the important state of personal safety and social responsibility to ensure control in the practice of responding to trauma. In this response, safety must be continually demonstrated.

But what are thin places in relationship to safety? Thin places are opportunities to connect with the past and the wounds of trauma. These thin places become safe not only when we secure their perimeters but also when they are transformed from places of death, destruction, and suffering into places that manifest new meaning. At La Pointe du Hoc, a promontory cliff overlooking the English Channel in Normandy, many of the original fortifications of the German army, including an observation bunker built into the rock, and deep cavities from bombs dropped on D-Day in June of 1944 still exist. Etched into the landscape are the symbols of human destruction and the dark side of human nature, but within these are new growth, grasses and flowers, alongside an impressive seascape that conveys both resilience and the potential for transformation after such destruction. The visible presence of vulnerability and endurance in a landscape reassures survivors of the possibility of recovery. Thus, the potential for growth promises security, even in the face of suffering.

13 Bessel A. van der Kolk and Alexander C. McFarlane, "The Black Hole of Trauma," in Traumatic Stress: The Effects of Overwhelming Experience on Mind, Body, and Society, eds. Bessel A. van der Kolk, Alexander C. McFarlane, Lars Weisaeth (New York: The Guilford Press, 1996), 18. 


\section{Reconstructing the trauma story: Memory and mourning}

As a place of trauma, La Pointe du Hoc bears "affective marks" in the landscape; at the 9/11 Memorial \& Museum artefacts such as massive steel beams buckled from the jet fuel that burned through the building evidence the effects of trauma. The marks can be considered traces of trauma which according to Ricoeur are the "primordial attribute of affections" that motivate us "to survive, to persist, to remain, to endure, while keeping the mark of absence and of distance" embodied by loss. ${ }^{14}$ To remain is to endure - and to remember the invisible and visible wounds of trauma. Whether the wounds are visible or not, the affective mark remains in the form of memories. Inscriptions-affections as traces assist in the recall of memory, and generally start at the level of the body. Ricoeur assesses that our bodies "contain the secret of the enigma of the mnemonic trace," or the patterns that aid us in remembering. ${ }^{15}$ Sensations and feeling in the body as a response to traumatic stimuli - seeing a loved one's name on the parapet or witnessing the bombed stained landscape in Normandy from over 70 years ago - direct witnesses to their personal pains. Bessel van der Kolk tells us, "the body keeps the score" of the memory of trauma. ${ }^{16}$

Remembering marks Herman's second stage of recovery which entails a retelling of the trauma, a piecing together of the past traumatic event and exploring future implications. In practice, this stage entails examining beliefs when confronted with the facts of human betrayal and evil (at least in traumas by human design), reconstructing a world where guilt and responsibility coalesce to form a moral universe where the victim is "undeserved of suffering," and exploring the question of "Why me?" while also examining what actions to take, often inspired by efforts towards justice. ${ }^{17}$ Thus, the individual at this stage of recovery finds herself at once "a theologian, a philosopher, and a jurist." ${ }^{18}$ Memorials and museums assume a similar role as employees are tasked with retelling and making sense of

14 Paul Ricoeur, Memory, History, Forgetting, trans. Kathleen Blamey and David Pellauer (Chicago: University of Chicago Press, 2004), 427.

15 Ibid.

16 Bessel van der Kolk, The Body Keeps the Score: Brain Mind, and Body in the Healing of Trauma (New York: Penguin Books, 2014).

17 Herman, Trauma and Recovery, 178.

18 Ibid. 
trauma. They must cultivate, as the Igbo do, a space that can contain and honour human suffering, while examining its implications and promoting reparation.

The activity of retelling is not a straightforward or simple act; in fact, it is characterized by fragmentation. The survivor must simultaneously live and be asked to tolerate ambiguity and uncertainty until integration - not "exorcism" - occurs. ${ }^{19}$ A memorialized place also attempts to integrate rather than exorcise. The $9 / 11$ Memorial \& Museum incorporates the event of the terrorist attacks with the present day to recollect the trauma and to assimilate it safely. The point is not to expunge the story from memory but to transform it, to create new meaning from it, and to reconcile it with present circumstances. Sites that commemorate trauma must be attentive to reconstruction which, according to Herman, includes recounting reality as it was before the trauma, along with reporting the details of the trauma itself - including and requiring the recall of sensory and bodily experiences. Without these Herman states, the story becomes "barren."

Recalling and retelling the trauma narrative includes the tasks of remembering and mourning, which challenge denial and help witnesses, survivors, and victims bear the magnitude of suffering. For instance, the 9/11 Memorial \& Museum sets out to tell the story of that day; alongside the narrative it leads visitors through an architectural tour that evidences destruction but which also reconstructs it to offer the possibility of deep engagement in the process of mourning, rebuilding, and making sense of events. Upon entrance into the museum, the visitor descends seven stories below street level to arrive at bedrock. In efforts to mitigate any overwhelming affect, museum planners and architects created a gradual path of descent, so that the going down and going into happens slowly. This element of the museum composes a descent narrative as a symbolic journey of doing the hard and sombre work of processing through trauma.

For individuals and communities, retelling the trauma story must be accompanied by uncovering memories which may be repressed. This requires addressing disruptive and disturbing recognitions to integrate the

19 Ibid., 180.

20 Ibid., 177. 
horrors of the event; time and space facilitate such integration. ${ }^{21}$ Integration requires not only recall but also modification and transformation. Memories must be contextualized and then "reconstructed in a personally meaningful way." 22 With new contextualization, apparent at sites that commemorate communal trauma, the trauma story becomes testimony. Herman lays out what is at stake in testimony from both a private dimension, she defines as "confessional and spiritual," and a public dimension, "which is political and judicial," ${ }^{23}$ therefore restoring meaning and establishing a pathway for social action.

Of equal necessity is the experience of mourning. Herman labels this stage as the difficult part of trauma recovery; yet, feeling grief is essential to recovery. ${ }^{24}$ Grief must take place in order to not be pathologized as a form of revenge or easy forgiveness of the perpetrator. ${ }^{25}$ Furthermore, as Herman states, "mourning is the only way to give due honour to loss; there is no adequate compensation." 26 For Freud, normal mourning - the grieving over a lost object of love - alleviates the possibility of the pathological turn he defines as melancholia, a problematic state where the ego is interpreted as worthless, abased, and somehow inferior. ${ }^{27}$ Refusing to mourn, thus accepting the shame that trauma inspires, is to give into the demand of victimization made by the perpetrator.

Effective memorialization resists victimization, providing opportunities for grieving and, in the reconstruction of memory, compelling consciousness. At an Interfaith Memorial Service on Yom Ha-Shoah, the Holocaust Memorial Day, Ricoeur spoke to the members of Emanuel Congregation asserting that the "The task of memory is to preserve the scandalous dimension of the event, to leave that which is monstrous inexhaustible by explanation." ${ }^{28} \mathrm{He}$ continues, "Thanks to the memory

21 Ibid., 185.

22 Van der Kolk and McFarlane, "The Black Hole of Trauma," 19.

23 Herman, Trauma and Recovery, 181.

24 Ibid., 189.

25 Ibid.

26 Ibid., 190.

27 See Sigmund Freud, The Standard Edition of the Complete Psychological Works, Vol. XIV, trans. James Strachey, (New York: W.W. Norton, 1976), 243-258.

28 Ricoeur, Figuring the Sacred, 290. 
and the narratives that preserve this memory, the uniqueness of the horrible - the unique uniqueness, if I dare say so - is prevented from being levelled off by explanation." ${ }^{29}$ Ricoeur thus establishes the ethics of memory as recalling and attending to the horrific acts that engender communal trauma. The effect of this is to allow the voices of the victims to be heard, prohibiting denial or repression of the propensity of human evil in the perpetrators' actions.

Memorials and museums reconstruct the trauma story to elicit such consciousness. Commemorating communal trauma presses awareness of the visible and invisible wounds precipitated by horrible acts and "rescue[ing] them from forgetfulness." ${ }^{30}$ Ultimately though, the task of the memorial museum is to reconstruct a story that honours memory in hope of healing traumatic wounds. The effort to heal wounds is embodied in Ricoeur's assessment that it is our duty to respond to tragedy with practical wisdom. In Oneself as Another, he reflects on tragedy in words that belie his five years in various prisoner-of-war camps in Germany and the suicide of his son Olivier to whom the section of the text on tragedy is dedicated. He writes, "One of the functions of tragedy in relation to ethics is to create a gap between tragic wisdom and practical wisdom." 31 Tragic wisdom in this case, locates us in an ambiguous realm where life and death intertwine challenging interpretations of what life is after immense suffering. ${ }^{32}$ In the deciphering, in the efforts to understand, we are located in the gap. The gap is at once the place where the past and present fold in on themselves in trauma - but it is also the place from where we act where we can respond to traumatic wounds. Historical sites of trauma make less ambiguous the space of the gap - as they arrest the past, remoulding it, and when they provide pathways for future promise, promote the possibility for new life after communal trauma.

Commemorating, educating, interpreting, and translating acts of violence in the thin place of a memorial and museum illustrates a practical response

29 Ibid.

30 Ibid.

31 Paul Ricoeur, Oneself as Another, trans. Kathleen Blamey (Chicago: University of Chicago Press, 1992), 247.

32 See Gabriel Marcel, Tragic Wisdom and Beyond, trans. Stephen Jolin and Peter McCormick (Evanston: Northwestern University Press, 1973), 206. 
to the tragic. This setting performs memory, serving as a testimony to traumatic wounding. The act of memorialization of communal trauma takes on the moral duty to speak for those who cannot - to tell their stories. This is not only for those who have lost their lives to acts of violence but also for the survivors and witnesses. In her book Unsayable: The Hidden Language of Trauma, Annie Rogers addresses how trauma consumes the basic ability to speak. She quotes poet Robert Pinsky: "What if I told you the truth? What if I could?"33 The word "could" conveys the impossibility of speech after trauma and communicates this notion of the "unsayable." The memorial museum then becomes a voice for all of those who cannot speak their truths, who cannot tell their stories.

The memorial attests to "the bond between the living and the dead" 34 and, in the efforts at truth telling, creates a bond between those who can speak and those who are silenced by trauma. This duty to reconstruct the trauma story emphasizes the relational nature of commemoration. The work of those in the memorial and museum takes on a special import. Ricoeur discusses this in terms of the archive, which he states serves as a physical entity that "shelters the destiny" of a documentary trace, a trace of the past in the present. ${ }^{35}$

Highlighting how employees at the 9/11 Memorial and Museum mediate the task of reconstruction, I share an antidote: An employee at the museum whose work consists of collecting the stories 9/11 victims' lives reported to me that at least once a month she holds a victim's story within her. As she talked about this she turned flush red assuring me that she did not feel "haunted" by the victims. But, still she claims, they are present in her life and in her body for a short duration. During this interval, she notices parallels between the victim's life and her own - a similar anniversary, a love of the same sport, animal, or food, or having lived in the same general area of New York City and so having frequented the same grocery store or restaurant. By carrying the victim in this way, she says, the victim's memory

33 Annie G. Rogers, The Unsayable: The Hidden Language of Trauma (New York: Ballantine Trade Books: 2007), 30.

34 Paul Ricoeur, Oneself as Another, trans. Kathleen Blamey (Chicago: University of Chicago Press, 1992), 245.

35 Ricoeur, Memory, History, Forgetting, 167 and 170. 
is not lost. This elective cradling of a traumatic narrative is common among employees at the museum - many recount stories about how they purposefully "hold" the victims' stories and lives, often to create empathy between themselves and family members. In this vein, the employees become minsters of memory, embodying memory, and embracing personal narratives. Employees as "guardians of memory" are also the beacons that introduce the next stage of recovery - reconnection.

\section{Restoring connection between survivors and their communities}

Traumas, especially those generated by human design, provoke a sense of a loss of control and feelings of deep isolation. Herman recognizes this effort at undermining individual mastery when she states that, "the perpetrator goes to great lengths to deprive his victim of any objects of symbolic significance." ${ }^{36}$ Part of this deprivation is the intentional severing of human connection, impregnating the bonds between people with doubt and confusion and isolating victims from others while also destroying internal images that signify the connection to others.

The terrorist attacks of September 11, and the many attacks that have occurred before and since, signify attempts of perpetrators not only to damage communities and individuals but also to immobilize trauma survivors' ability to respond to traumatic events - the intent (which is at least temporarily successful) is to freeze survivors and witnesses in a zone of terror, incomprehension, and absurdity. The process of recovery, then, depends on re-establishing relationality and restoring symbolic significance, something that the memorial museum structures and grounds suggest by transforming the elements that were present prior to the terrorist attacks into something that creates new opportunities for growth, understanding, and trust in the self and others. Memorials and museums that illustrate the courage of responders, victims, and survivors in the face of adversity, alongside promises for future hope, play an active part in the reestablishment of human connection as they facilitate trust or confidence in individual and communal resilience.

36 Herman, Trauma and Recovery, 80. 
Part of trusting includes being close to oneself and close to others - what Herman calls identity and intimacy, aspects central to trauma recovery. ${ }^{37}$ And so she situates the statement, "I know I have myself" as the primary attribute of the third and final stage of recovery. ${ }^{38}$ At this point, "the survivor no longer feels possessed by her traumatic past; she is in possession of herself." 39

This returns us to the Ricoeurean imperative - to remember, we need the other. Recovery from trauma necessitates the other in the form of genuine human connection which fosters attachment and rejuvenation. On a very physical level, such human communion takes place on the memorial to September 11 every day - when people trace the names of the dead on the parapets, and when employees place a white rose at the name of victims who have a birthday that day. This touching serves as a conduit of memory, preserving the connection between those lost and those who remember them.

"Between the lived space of the lived body and the environment" 40 at the memorial, an exchange happens, as with thin places, between death and life, between the past and the present, and between this world and the next. The gap that encompasses this exchange constitutes a third space, detailed by Ricoeur as facilitated by the role of architecture - here the memorial pools. Psychoanalysts call this third space the place of creation encapsulated by genuine contact with another at a deep level of emotional experience which fosters something new. This genuine contact requires an awareness of the primordial body and often facilitates a meaningful realization of connection to another human being.

The formidable encounter with the other can also be interpreted as the collision of the present world and the transcendent. In Jung, it is the coniunctio experienced when mutual reciprocity (to use Ricoeur's term) is achieved between people. If we extend the concept of the gap here, as the place of habitation of this analytic third, the gap becomes the in-between, the past and present in trauma -conceptualized in the notion of thin place.

37 Ibid., 207.

38 Ibid., 202.

39 Ibid., 202.

40 Ricoeur, Memory, History, Forgetting, 150. 
In this case, it is the body that is the location where the real world and the transcendent collide, because the body functions as the perceiver, through affective forces, of the "thin place."

The past, present, and future converge in the body as the conductor of memory. The body listens; the body speaks. The body acts as a translator of the traumatic experience, of memory, of the sacred. The body serves as the interpretive guide of traumatic narrative, a body which may also bear the wounds of other unrelated trauma(s). Visiting memorial sites then constitutes listening to trauma in order to restore the connection between survivors and the community.

\section{Conclusion}

The narrative of trauma retold at memorial and museum sites must remain directed to "the question of the end." ${ }^{41}$ As Ricoeur asserts, "If trauma refers to the past, the exemplary value is directed towards the future" - to the development of justice, prudence, and courage. ${ }^{42}$ Further, sites of memory foster individual and social practices that tend towards transformation and growth when they point to the moral duty that emphasizes the debt owed to the victims, when they press witnesses to be good listeners. In Ricoeur's ethics, in order to do this fully, participants must inhabit and listen to their bodies. This ethical imperative reflects in Herman's first stage of trauma recovery: bodily regulation and the establishment of safety. And yet, the imperative does not end there.

From both a philosophical and psychological point of view, remembering must be done and must be done consciously, attending not only to the personal traumas evoked in places of memorialization but also to what was lost in the contextual trauma. For Herman, this marks the second stage of trauma recovery - memory and mourning in the reconstruction of the trauma story, as it prepares us to carry the "living memory of survivors" forward. ${ }^{43}$ To remember well is to direct memory toward justice. Part of justice includes refuting the efforts of perpetrators to undermine selfworth and divide communities. From a theological standpoint, integrity

\footnotetext{
41 Ibid., 86.

42 Ibid.

43 Ibid., 87.
} 
and love live alongside justice, prudence, and courage. These circulate in the gap between trauma and its memory. According to Shelly Rambo, after trauma, love remains as the "middle term between death and life." ${ }^{44}$ At the historic sites of communal trauma, death and life hang in the balance; this is the thin place. Remembering and mourning death paves the way for the development of new life. The reconstruction of places of trauma foster human creativity, action, and connection, critical to recovery. And after communal trauma, community and action are critical to challenging passivity. These needs are mobilized in the environment of memorial museums and, when made conscious, enable the processing of trauma on both individual and societal levels.

Remembering well and together at historic sites that commemorate trauma combats the risk of forgetting; to forget the trauma, as Herman asserts, is the wish of the perpetrator. Alongside this wish is the hope to divide communities. To submit to forgetting and to disconnection is to surrender to effacement, to make ourselves and our communities inconspicuous. ${ }^{45}$ And effacement includes not only a forgetting of history, but also a wiping out of the affective mark of trauma, which, whether we are survivors or witnesses, constitutes who we have become. To remember trauma at a "thin place" of communal suffering is then to hold and bear these wounds - for witnesses, for survivors, and for the victims.

\section{Bibliography}

Felman, Shoshana and Dori, Laub M.D. 1992. Testimony: Crisis of Witnessing in Literature, Psychoanalysis, and History. New York: Routledge.

Freud, Sigmund 1976. The Standard Edition of the Complete Psychological Works, Vol. XIV. Translated by James Strachey. New York: WW Norton.

Gomes, Peter J 1996. The Good Book: Reading the Bible with Mind and Heart. San Francisco: Harper Collins, 1996.

44 Rambo, Spirit and Trauma, 133.

45 Ricoeur, Memory, History, Forgetting, 506. 
Herman, Judith 1992. Trauma and Recovery. New York: Basic Books.

Husserl, Edmund 1999. Cartesian Meditations: An Introduction to Phenomenology. Translated by Dorion Cairns. 1950. Reprint. Dordrecht: Klewer Academic Publishers.

Lefebrve, Henri 1991. The Production of Space. Translated by Donald Nicholson-Smith. Oxford: Blackwell Publishers.

Marcel, Gabriel 1973. Tragic Wisdom and Beyond. Translated by Stephen Jolin and Peter McCormick. Evanston: Northwestern University Press.

Oduyoye, Mercy Amba 2004. Beads and Strands: reflections of an African Woman on Christianity in Africa. New York: Orbis Books.

Rambo, Shelly 2010. Spirit and Trauma: A Theology of Remaining.

Louisville: Westminster John Knox Press.

Ricoeur, Paul 1995. Figuring the Sacred: Religion, Narrative, and Imagination. Translated by David Pellauer. Minneapolis: Fortress Press.

- 2004. Memory, History, Forgetting. Translated by Kathleen Blamey and David Pellauer. Chicago: University of Chicago Press.

- 1992. Oneself as Another. Translated by Kathleen Blamey. Chicago: University of Chicago Press.

Rogers, Annie G 2007. The Unsayable: The Hidden Language of Trauma. New York: Ballantine Trade Books.

Sellner, Edward C 1993. Wisdom of the Celtic Saints. Notre Dame, IN: Ave Maria Press.

Ulanov, Ann Belford 2007. The Unshuttered Heart: Opening Aliveness/ Deadness in the Self. Nashville: Abingdon Press.

Van der Kolk, Bessel 2014. The Body Keeps the Score: Brain Mind, and Body in the Healing of Trauma. New York: Penguin Books.

Van der Kolk, Bessel A and McFarlane, Alexander C 1996. "The Black Hole of Trauma." In Traumatic Stress: The Effects of Overwhelming Experience on Mind, Body, and Society. Edited by Bessel A van der Kolk, Alexander C McFarlane, and Lars Weisaeth. New York: The Guilford Press. 3-23. 